\title{
The aerotropolis: Urban sustainability perspectives from the regional city
}

\author{
Reza Banai \\ University of Memphis \\ rbanai@memphis.edu
}

\begin{abstract}
The aerotropolis-a metropolitan region with cities that capitalize on proximity to a globally networked economy's airport-is regarded as the twenty-first century's new urban-development paradigm. Similarly, the regional city-a polycentric metropolitan region with linked mixed-use centers, multi-modal corridors, multi-functional districts, and natural preserves-is regarded as an urban form of the future with global and local advantage. In this paper, the building blocks of the regional city, which are increasingly regarded as principles of a durable urbanism, inform a multi-criteria framework toward a sustainability assessment of the aerotropolis-built form. The implications for the redevelopment of a North American city as an aerotropolis are noted. The paper concludes with an expansive discussion of the sustainable urban form of the future.
\end{abstract}

Keywords: aerotropolis, airport city, regional city, urban form, building blocks, urban sustainability

\section{Article history:}

Received: October 23, 2015

Accepted: February 8, 2016

Available online: December 15, 2016

\section{Introduction}

Transportation is a determinant of urban form. Kasarda (2006) argues that the city of the twenty-first century is shaped by its "multi-modal, multifunctional enterprise" — airports—-hence deserving the appellation aerotropolis. In a "new speed-driven, globally networked economy," airports cater to demand for transportation and communication with prompt and flexible service (Kasarda 2006, 2011). Whole new towns burgeoning in vast open spaces or greenfields (undeveloped land prime for agriculture), and in redeveloping brownfields (formerly industrial and manufacturing sites now abandoned and toxic sites that require cleanup) of the emerging or revitalizing Asian, European, American, Middle-Eastern, and African economies capitalizing on airport proximity for global business are evidence of the new paradigm.

The aerotropolis urban form has an airport as its core "airport city" and a periphery in which aviation-related enterprises take advantage of proximity to the airport (Figure 1). [Aerotropolis and "airport city" are used indiscriminately in the literature. For example, Memphis's airport city is a 50 squaremile sub-area of the greater metropolitan region that includes suburban municipalities that define the "Memphis Aerotropolis." However, the "Atlanta Aerotropolis" is an even smaller 122-acre site (Lindsay

Copyright 2016 Reza Banai

http://dx.doi.org/10.5198/jtlu.2016.889

ISSN: 1938-7849 | Licensed under the Creative Commons Attribution - Noncommercial License 3.0

The Journal of Transport and Land Use is the official journal of the World Society for Transport and Land Use (WSTLUR) and is published and sponsored by the University of Minnesota Center for Transportation Studies. 
and Kasarda 2013, 149).] The urban function in the metropolitan region is similar to that of the central business district of the twentieth-century metropolis (Kasarda 2006, 63). Roads and rail transit provide regional mobility. And the aerotropolis has mixed-land use with variable density.

The economic and environmental impact of airports both within their sites and in the larger regions surrounding them is increasingly documented (e.g., Hakfoort et al. 2001). In the literature of the economics, logistics, infrastructure, and even spatial planning of the aerotropolis (Twomey and Tomlins 1995; Banister 1995; Hakfoort et al. 2001; Freestone 2009; Freestone and Baker 2011), however, scant attention is given to the physical-form building blocks of the aerotropolis. Discussions of urban sustainability increasingly link environmental consequences - greenhouse gases and climate change- to the physical form of cities and regions and their transportation systems (Ewing et al. 2008; UN Habitat 2009; Calthorpe 2011). Urban-sustainability literature plausibly regards the metropolitan region as the appropriate geographic scale of twenty-first century global trade and communication (Wheeler 2000, 2002, 2009; Calthorpe and Fulton 2001; Pastor et al. 2000; Hall and Pain 2006; Ross 2009). The term aerotropolis, as coined by Kasarda (2011), also connotes an aviation-centric metropolitan region.

It turns out that a nascent paradigm with an emphasis on the physical form of cities and regions that is simultaneously mindful of the environmental, social, and economic consequences informs contemporary discussions of urban sustainability. The twenty-first century's new regionalism revives the twentieth century's regionalism, which placed the city's sustainable growth and development in a regional context (Hall 1996; Fishman 2000; Katz 2000). The holistic physical-planning principles are revived, reformed, and applied in the planning and design of what Calthorpe and Fulton (2001) call the regional city. The regional city is also regarded as the urban form of the twenty-first century (Calthorpe 1993; Bernick and Cervero 1997; Wheeler 2009; Calthorpe and Fulton 2001; Wheeler 2002). Portland, Salt Lake, Seattle, Vancouver, Stockholm, and Singapore are cited as evidence of sustainable urbanism that heed regional city principles (Bernick and Cervero 1997; Calthorpe and Fulton 2001; Wheeler 2009, 2002). Compact urban form that supports public transit and walkability; centers that are mixed-land use and connected by multi-modal corridors; housing mix that accommodates diverse demographics and is in balance with jobs; easily accessible, centrally located civic spaces that contain the city's commons; and an urban-growth boundary that favors the preservation of open space, limits sprawl into exurban agricultural land (greenfields), and encourages infill and redevelopment of vacant properties are among the features attributed to a sustainable urbanism. Notwithstanding their detractors, these features are identified in discussions ranging from new urbanism and new regionalism to smart growth, sustainable naturalism, landscape urbanism and the like (for example, see Breheny 1992; Breheny 1996; Jenks et al. 1996; Katz 2000; Flint 2006; Kotkin 2007; Calthorpe and Fulton 2001; and Duany and Talen 2013). Furthermore, the regional city provides historical, conceptual, and practical perspectives that inform discussions of sustainable urban form. Transit-supportive corridors of the regional city assimilate an urban form conceptualized around the turn of the nineteenth century (Howard 1898/1902). Replication and revival of Howard's Garden City idea in twenty-first century American, European, and Asian regional cities is evidence of durability of the urban form concept in practice.

Toward sustainability assessment of the aerotropolis's urban form, we set out a framework that incorporates the regional city's "building blocks" (Calthorpe and Fulton 2001). Our aim is for the building-blocks framework to axiomatically inform planning and design discussions of a sustainable urban form while bearing in mind that each urban context is unique, and that assessment of sustainability, therefore, is site-specific. "Situations and values differ," as Lynch $(1984,111)$ would say, and therefore each aerotropolis is likely valued differently in deference to local circumstance. [Compare Lynch's (1984) five criteria considered not as "standards" but as "performance dimensions" that assess urban form.] However, our framework incorporates the regional city's building blocks in assessing sus- 
tainability by elemental urban form. We cite examples of European and Asian airport-oriented cities, as well as a North American city slated for redevelopment as an aerotropolis to show how this framework informs aerotropolis-sustainability planning-and-design discussions. A discussion of the redevelopment of Memphis, TN, as "America's Aerotropolis," as has been recently proposed, suggests the merits and limits of the proposal for a city that would effectively redevelop as both an aerotropolis and a regional city. We conclude with a note on regionalism and a concept of environmental sustainability-the carbon footprint-laden with physical manifestation as well as economic and social implications for sustainable urban form of the future.

\section{Toward an assessment of the aerotropolis with the building blocks of the regional city}

Does the aerotropolis resemble the regional city's building blocks? Could it be that the aerotropolis's ideal urban form is a regional city like Amsterdam? (Kasarda 2006, 2011) The building blocks of the regional city are briefly defined thus (for a thorough exposition, see Calthorpe and Fulton 2001, 52-60):

\subsection{Centers}

Mixed-land use in nodal locations characterizes the regional city's center at any scale-from neighborhood, to village, to town, to city, to region. Central locations of jobs, housing, and civic facilities ensure access, particularly when linked throughout the region with multi-modal transportation. "Core commercial areas" provide economies of agglomeration for businesses and firms in a nodal location, and the benefit of accessibility for households. Compare Hotteling's (1929) principle of minimum differentiation (see also Brown 1990, 1992; Banai 1998). An indicator of the center's (intra)accessibility is pedestrian-friendly land use-particularly due to housing-retail-office mix in proximity to transit stops, as is multi-modal (inter)connectivity of centers.

\section{$2.2 \quad$ Districts}

The regional city's centers are mixed-use, fine-grained, and pedestrian-scale. Centers therefore exclude the land use that characterizes areas with a predominantly urban function, typically with large building footprints, such as university campuses, industrial warehouses, big-box retail stores, and airports. The regional city accommodates these coarse-grained uses in its districts rather than its fine-grained, mixeduse urban centers. Districts identify the function of the metropolitan sub-areas thematically. When there exists thematic unity, the identity and legibility of the city-district image is enhanced (Lynch 1960). The viability of central business districts linked to imageability is one example. Corridors and centers contribute to the viability of districts with legible landmarks. The compact urban form prevents sprawl-a liability - within the district. Furthermore, a chaotic urban form (sprawl) contributes to a lack of legibility (see also Lynch 1960, 1976). For discussion of corridor, district, and node in airport-development planning see Blanton 2004; Schaafsma, Amkreutz, and Gukker 2008; Lee, Gosling, and Irvin 2008; Freestone 2009; Freestone and Baker 2011.

\subsection{Preserves}

The regional city is identified by natural characteristics - physiographic and aquatic features, and greenfields attributable to the metropolitan region's geographic location in nature. The preserves are the natural regional city's boundaries or edges, like San Francisco's bay and Seattle's waterfront. The preserves also provide natural buffers — open spaces, greenbelts, and the like—between communities in the regional 
city. The regional city's communities are thus uniquely identified. Regional ecosystem connectivity-including multi-purpose watershed management with scenic (recreational) and local drainage, and flood control - is valued. The preserves provide natural clue to planning and design at the regional scale, with features that cross municipal boundaries (McHarg 1969, 1995; McHarg and Steiner 2006; Calthorpe and Fulton 2001; Farr 2008; Barnett 2011). The environmental consequences of urban growth that does not respect the region's ecology are well-known.

\section{$2.4 \quad$ Corridors}

The region's ecological systems form natural corridors, such as ridges, open spaces, rivers, and streams. The interconnection of the natural systems ensures the region's viability. Corridors form the "skeletal" structure that defines the region's future. Equally important to the quality of life are the region's humanmade corridors - transportation systems. The multimodal structure of corridors similarly contributes to the region's vitality. Multi-modal connectivity in transportation corridors exemplify the regional city.

The building blocks are mutually enhancing. For example, if the corridor is light-rail or bus-rapid transit (LRT or BRT), transit-oriented developments (TOD) offer the advantage of central places in which to live with access to jobs throughout the metropolitan region's connected centers (Calthorpe 1993; Bernick and Cervero 1997; Calthorpe and Fulton 2001).

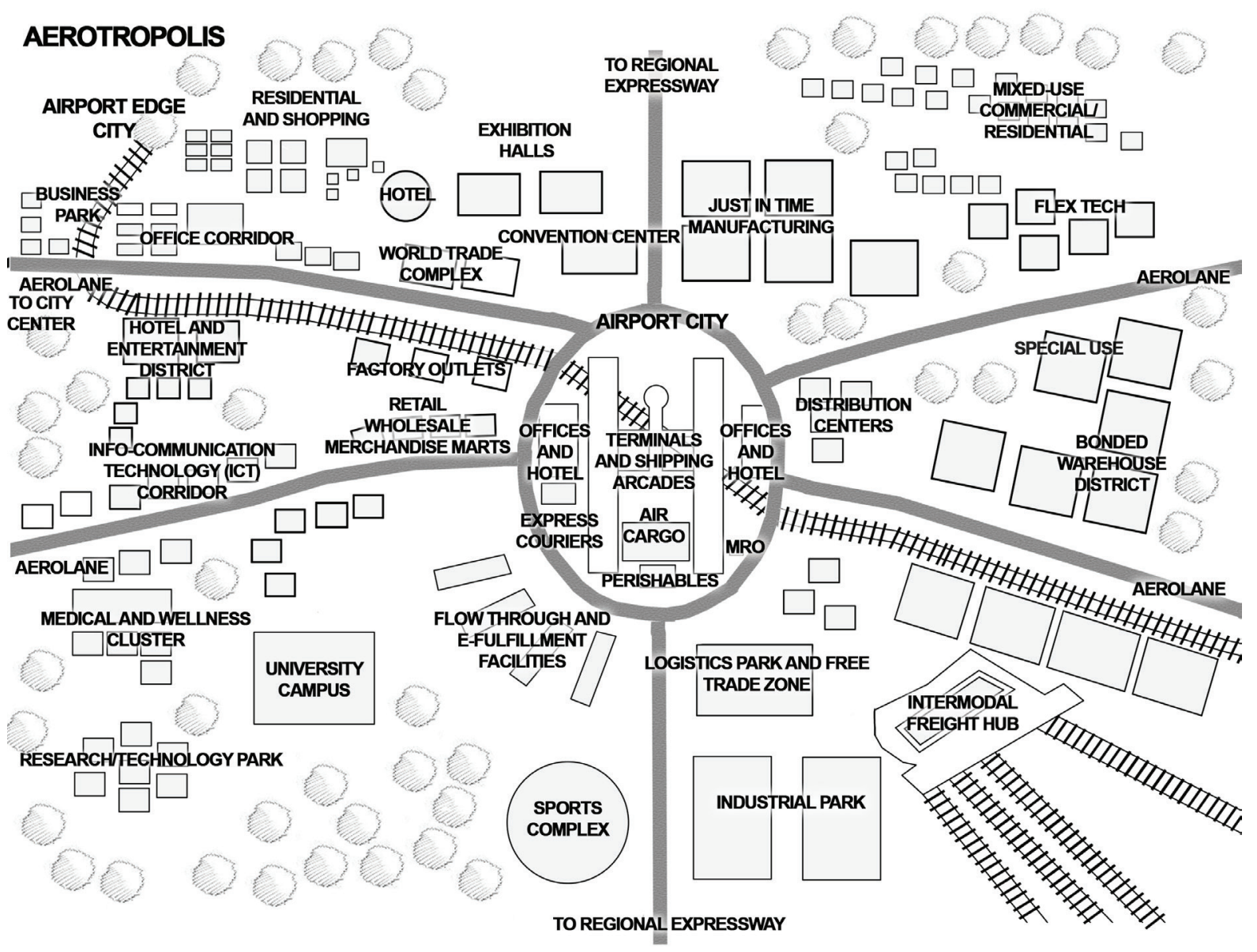

Figure 1: Kasarda's vision of the aerotropolis is a city-region anchored by a globally networked economy's airport (adapted from: Aerotropolis, http://aerotropolis.com) 
The building blocks of Kasarda's Aerotropolis are shown schematically in Figure 1. The airport at the city's core is surrounded by land uses that are predominantly logistically linked to aviation function. At first glance, the twenty-first century airport city conceptually recalls the early twentieth-century monocentric, concentric-zone model of urban growth (Burgess 1923). However, upon empirical scrutiny, a polycentric metropolitan region is observed (Appold and Kasarda 2013; see also Hall 2001). The monocentric city is the "basic model of urban form" as Appold and Kasarda (2013) aptly remind, however, the city that is diagrammed schematically and verified empirically has features, like "edge city," that connote the polycentric urban form beyond the "basic model." Compared to the twentieth-century city, in which economic and social vitality is concentrated in a central business district (CBD), the airportcity district as a whole determines a vital function that is not confined to the city center. Therefore, the airport city as a district is akin to the concept of district in the regional city. Its transit-supportive "edge city" further indicates a polycentric metropolitan region. The aerotropolis is dissimilar to Burgess-like monocentric urban form (Burgess 1923). Rather, the aerotropolis is better considered alongside Hoyt's sector theory, given the role of the transportation corridor in city growth and development (Hoyt 1939), and is even more aligned with Harris and Ullman's multiple nuclei theory of urban growth (1945), given the sustained functional roles of the CBD and similar other mixed-use districts in the metropolitan region's edge cities and edgeless cities (see also Garreau 1991; Lang 2003).

Hakfoort, Poot, and Rietveld (2001) provide empirical evidence of the impact of employment growth of Schiphol airport on the Amsterdam metropolitan region. One airport job results in one indirect and induced job in the region. Hakfoort, Poot, and Rietveld $(2001,603)$ characterize the "dual function" of airports as "transport nodes" and as "growth poles' in the regional economy." Although empirical estimates of the employment impact of Schiphol airport are given for the Amsterdam metropolitan region, the possible impact elsewhere at distances beyond the airport in the region particularly in cities with road and rail connection to Schiphol, such as in cities of Rotterdam, The Hague, and Utrecht is acknowledged. The additional services - including housing - that are associated with the growth in employment in the sub-region are expected, with a little help from economic-base theory.

Furthermore, regional growth is explained by agglomeration economies (Atzema 1999). Hakfoort et al. (2001) attribute the differential growth of the Amsterdam's sub-regions to agglomeration effects of (Schiphol) airport-related wholesale and transportation sectors. The sub-regions with higher shares of these sectors fared better than other sub-regions, and even better than the national average. Other studies highlight the impact of airport and airport expansion on firm location or relocation decision, e.g., Rietveld and Bruinsma (1998) and Markusen, Saxenien, and Hall (1986) reference growth in high-tech sectors.

Location theories that map out the airport's space-economy with impact on business decision, industry decisions, and operations inform the airport-centric aerotropolis. However, location theories tell us little about the aerotropolis's physical form - its land-use mix and density, share of civic and open spaces, walkability of the streets and neighborhoods, and the quality of life that influences both firms' and households' location decisions. We draw on regional-city principles and practices toward sustainability assessment of the aerotropolis's physical form. Furthermore, the principles address not only the spatial form of the mixed-use walkable centers, but also business and industrial sectors like logistics, distribution, warehousing, and large-footprint "big box" retailing that are a vital part of the metropolitan region's form and function

The aerotropolis sustains the twenty-first century's multi-modal (runway, rail, and roads) urbanism. Although the river is not shown, (cargo) rail and (truck) road imply the river's viable function in multi-modal freight transportation, as touted in the redevelopment of Memphis as an aerotropolis (see Greater Memphis Chamber 2013). The land-use is mixed, with industrial, service, civic, and residential uses, and green space that comprise a (sub)district. There is density variation within the district as a whole. The proximity of the offices and hotels to the main terminals, also accessible by passenger train, 
implies a pedestrian-friendly airport city-center. Remarkably, even the "airport edge city," shown in the north-west, is mixed land use and served by passenger rail, making the aerotropolis core employment, and other uses in nodal locations, accessible from the periphery. With rail access, the air transportationdependent aerotropolis effectively surmounts a limitation of the auto-dependent twentieth-century edge city. Schematically, the aerotropolis building blocks resemble the regional city. The segregated land-use that characterizes the auto-dependent office park and suburban sprawl of the twentieth-century, however, drastically differ from the fine land-use grain and pedestrian-friendly, continuous road network of a sustainable urbanism.

The aerotropolis mixed-land use is also akin to the regional city. The mixed-land use's central location is a feature of the regional city. Our assessment of the exemplary airport-oriented cities hinges upon this fundamental feature of the regional city. Furthermore, the nodes of the aerotropolis are linked with multi-modal transportation, including rail transit, as illustrated by the Kasarda conceptual model (Figure 1). However, our assessment of aerotropolis access is based not just on the multi-modal connection of the activity nodes within the airport city (district), but also throughout the metropolitan region-a fundamental feature that ensures the regional city's population mobility and access to employment and service centers. The twenty-first century metropolitan region is a spatial structure with polycentric activity nodes (Bernick and Cervero 1997; Calthorpe and Fulton 2001; Hall and Pain 2006). If linked with rail as well as road, then the competitive advantage of the regional city—with urban sustainability due to multi-modal mobility and access to jobs and services - is realized in the aerotropolis. Our assessment of the exemplary airport cities as well as the potential for redevelopment of city airport as airport city and ultimately as an aerotropolis thus considers multi-modal connectivity of the polycentric activity nodes thought the metropolitan region.

In the following section, we highlight those building blocks that the aerotropolis has in common with regional cities. We briefly discuss the challenges of a city airport's transformation to an airport city and eventually to an aerotropolis that is also a regional city. Our focus here is on the conceptual framework rather than on in-depth empirical analysis of urban form; however, our intention is for the building-blocks framework to inform city-specific empirical analysis. Furthermore, we do not attempt an exhaustive survey of airport cities (see, e.g., Lindsay 2006; Kasarda and Lindsay 2011; Yu 2011).

\section{A comparison of aerotropolis and regional-city building blocks}

We include in Table 1 an example of an aerotropolis (Amsterdam) that has evolved historically in the course of centuries as a "seaport-airport corridor" connecting Europe to the rest of the world. We also include an example of an emerging, master planned Asian aerotropolis built "instantly" (Songdo near Incheon airport, South Korea). A North American city with a redevelopment plan for an aerotropolis (Memphis, TN) is plausibly regarded in the context of both historical and "instant" airport cities. [Alexander (1965) ascribed the term instant cities to the planned new towns-like Greenbelt, Maryland - that were constructed in greenfields "all in a piece," as Lang (1984) would say, and contrasted their physical forms with cities that evolve over the course of centuries.] The instant airport cities have the benefit of a "clean sweep," - such as the planned 1500 acres of Songdo near Incheon airport - commonly in vast greenfields or open spaces that provide the flexibility of master planning all in a piece. Closed airports also provide large sites for new town development, as in the former site of Denver's 4700-acre Stapleton airport (see project description in Calthorpe and Fulton 2001, 226-227). In contrast, airport-city redevelopment is limited to availability of vacant or underused land whose development potential encounters the challenge of the regional city's compact urban form, mixed-use centers, jobs-housing balance, and multi-modal connectivity of centers in corridors and districts (as we will note 
later in the case of Memphis, proposed for redevelopment as an aerotropolis). The three examples cited here should reveal the desirable features of the regional city that are shared with the aerotropolis while identifying the challenges of planning and designing an airport city that is as a phased development part of an aerotropolis. If not master planned, a city airport is transformed into an aerotropolis with incremental projects, and land-use planning and control (for a listing of cities with aerotropolis-type planning projects, see also Yu 2011; for an assessment of Schiphol's land-use planning and control, see Van Wijk, Brattinga, and Bontje 2011).

Table 1: Assessing the urban form of aerotropolis by using regional city building blocks

\begin{tabular}{|c|c|c|c|c|c|}
\hline Building Block & Centers & Districts & Preserves & Corridors & Assessment \\
\hline $\begin{array}{l}\text { Zuidas, Aalsmeer, } \\
\text { Amsterdam } \\
\text { (Schiphol) }\end{array}$ & $\begin{array}{l}\text { town centers with } \\
\text { mixed land use; office, } \\
\text { retail, hotel. }\end{array}$ & $\begin{array}{l}\text { Amsterdam Airport } \\
\text { Area (AAA) Zuidas } \\
\text { (business district) } \\
\text { Aalsmeer ("global } \\
\text { floral hub") airport } \\
\text { city district }\end{array}$ & $\begin{array}{l}\text { built on a drained } \\
\text { lake; agriculture/ } \\
\text { greenbelt; World's } \\
\text { "green (flower) hub." }\end{array}$ & $\begin{array}{l}\text { multimodal, roads, } \\
\text { trains, rail. Aalsmeer } \\
\text { Shuttle (underground } \\
\text { rail to Schipol) Zuidas } \\
\text { (six mile drive or train } \\
\text { to Schiphol) }\end{array}$ & $\begin{array}{l}\text { district with regional centers; } \\
\text { housing in proximity; district is in } \\
\text { a regional city with multimodal } \\
\text { mobility }\end{array}$ \\
\hline $\begin{array}{l}\text { Songdo, Seoul } \\
\text { (Incheon) }\end{array}$ & $\begin{array}{l}\text { mixed land-use } \\
\text { with hotels, offices, } \\
\text { warehouses; planned } \\
\text { new town }\end{array}$ & $\begin{array}{l}\text { Yeongjong Island (Air } \\
\text { City) International } \\
\text { Business District } \\
\text { (IBD) }\end{array}$ & $\begin{array}{l}\text { bounded by sea; } \\
40 \% \text { green space in } \\
\text { IBD; } 100 \text { seawater } \\
\text { canals in } 100 \text {-acre } \\
\text { Central Park }\end{array}$ & $\begin{array}{l}\text { multimodal road, } \\
\text { bridge to airport, tun- } \\
\text { nel, ferry, rail (high } \\
\text { speed commuter link } \\
\text { to Seoul ) }\end{array}$ & $\begin{array}{l}\text { multimodal, high density, "smart" } \\
\text { and green city with mixed-use } \\
\text { regional center with proximity to } \\
\text { housing in Songdo Island }\end{array}$ \\
\hline
\end{tabular}

Sources: Thorpe (2013), Williamson (2013) for Songdo; Lindsay and Kasarda (2013) and Vision Zuidas (2009) for Amesterdam.

\subsection{Zuidas, Amsterdam (Schiphol)}

Notwithstanding the Netherlands' high carbon footprint (Pierce 2007; Wackernagel and Rees 2009), Amsterdam is noted for its exemplary urban-sustainability practices. Compact urban form, integrated multimodal activity centers with mixed-use including residential population with public transit mo- 
bility options, pedestrian-friendly shopping areas, strengthened urban core, concurrent planning for housing and public transit in new growth areas, and redevelopment of the older, dilapidated city center (as in eastern docklands) are among "green urbanism" practices of the European cities also observed in Amsterdam (see Beatley 2009). With regard to preserves, the city is also the location of a development project (GWL-Terrein) built on "city's old water works site," which includes 120 community gardens and is served by transit (Beatley 2009, 334). Beatley $(2009,332)$ notes, Java-eiland district is diverse and distinctive, with "a series of canals and building scale reminiscent of historic Amsterdam" and uniquely modern pedestrian-bridge crossings.

The "mega-aerotropolis" scale is a result of a deliberate partnership—Kasarda and Lindsay (2011, 190) define the Amsterdam Airport Area as "the airport, port, city of Amsterdam, and the sounding provinces." Among the mega-aerotropolis's advantages are regional land use and transportation planning and implementation across jurisdictions. Amsterdam is a regional city, and its airport area is a cohesive district. Schiphol is a major node of industry, businesses, firms, offices and jobs. Unlike a regional city center with mixed use, however, Schiphol does not have housing for its employees. In contrast, the new town of Zuidas is within "six minute drive or train ride" of Schiphol (see also Vision Zuidas 2009). Kasadra and Lindsay $(2011,191)$ compare it with Las Colinas with a similar proximity to DFW airport. The housing locations' proximity to the regional city's employment nodes via mixed land-use and public transit (including commuter and light rail) compensates for the lack of housing in the airport area itself. (Compare the limited mix in airport-city concept outlined in Figure 1.)

Schiphol is a major employment node; however, its employees' residences are in regional (provincial, in the case of Randstad, Holland) cities. Not all of the metropolitan region's activity nodes are self-contained, as Howard $(1898,1902)$ imagined, balancing housing and jobs and services. However, a hallmark of a sustainable urbanism is the linked polycentric region and multimodal corridors, prominently including (rail) transit that provide regional mobility and access from places of residence to job and service nodes - in contradistinction to rail-transit systems that link job nodes but not residences, perpetuating auto-dependence and park-and-ride facilities. With European green urbanism features that render Amsterdam an exemplary regional city, it is little wonder that is also regarded as an aerotropolis's ideal urban form (Kasarda 2006).

\subsection{Songdo, Seoul (Incheon)}

Songdo Island contains mixed residential, commercial, and educational land uses with proximity to an airport (Incheon). The phased development plan includes airport-related industries, commercial facilities, and housing for the airport's employees. Like other cities with airport-downtown rail-transit connections, Incheon is linked to downtown Seoul by both commuter and express subway lines (Songdo Master Plan 2014). The commuter line has stations spanning its entire length in parallel with Airport Railroad Express (AREX), the express subway line, which suggests multi-modal corridor connectivity throughout the metropolitan region (www.airport.kr/iiacms). Songdo's global central business district is aptly termed "international business district" (Thorpe 2013) with multimodal transit connection to Seoul and Incheon (airport). In contradistinction to the car-dependent sprawling edge city, this Asian edge city is multimodal, and therefore akin in mobility aspect to regional city (recall Figure 1).

Urban sustainability is further defined from "roof top to region" (Birch and Wachter 2008; Banai 2013). Thorpe (2013) highlights Songdo's buildings that are LEED standards [US Green Building Council's (usgbc.org) leadership in energy and environmental design, LEED); for examples of urban sustainability indicators and benchmarks from building site to region, see Banai 2013.] If you live in Songdo, you have a fifteen-minute walk to the city center and central park (Williamson 2013). We live in a "regional world," Calthorpe and Fulton (2001) remind us. A metropolitan region's mixed residen- 
tial, office, and commercial centers at any scale, from small town to the big city, are sustainably linked with rail transit in the world's exemplary, greener regional cities, from developing to developed countries (e.g., see Rabinovitch and Leitman 1996; Moore 2007; Yaro and Kooris 2008). [Recall long-term land-use-transportation planning for Portland, OR, as a sustainable regional city of the future resulted in a rail-transit alternative to highway extension. See discussion of land use-transportation-air quality connection (LUTRAQ) in Calthorpe and Fulton 2001).] Songdo's compact urban form, proportionate commercial (40), residential (35), retail (10), hospitality (5), public green space (10), (million SF), and multimodal corridors that connect regional centers await businesses and households that consider the benefit of working and living in an aerotropolis that is akin to a regional city.

\subsection{Memphis, airport city, aerotropolis (MEM)}

The planned redevelopment of Memphis, TN, as "America's Aerotropolis" capitalizes on Memphis's geographic, multi-modal advantage as a "distribution center" — the hub of FedEx —with runway, road, rail, and river (www.memphischamber.com) (Table 1). Corridors are classified by types of land-use, such as logistics, office, medical, cultural, education, and entertainment, along major arterial roads and highways (http://www.memphischamber.com). Automotive mobility and limited land-use mix, rather than balance of cars and transit and mixed-use centers that are a hallmark of a sustainable regional city, are immediately implied. In the regional city, the multi-modal transportation corridors serve centers that are mixed in land use at any scale - from the neighborhood, village, and town to the region. The "Aerotropolis Corridors" map, however, does not include any designation of the centers that are linked by the Memphis Aerotropolis's transportation systems, in contradistinction to an earlier Memphis 2000 Policy Plan's (Memphis and Shelby County Office of Planning and Development 1981) remarkable, regional city-like "high-capacity transit" corridors and urban centers with variable land-use mix and intensity.

Even though the Memphis light-rail transit (LRT) plan is shelved in favor of bus rapid transit (BRT), the current Aerotropolis Master Planning Initiative offers an impetus to resurrect LRT with its proposed transit-oriented developments (TOD). These developments could provide affordable housing and regional-mobility options with access to the city's job centers (particularly the industrial, commercial, and warehousing centers). If the LRT plan is revived in a manner consistent with the Regional Transportation Plan of "high-capacity transit" corridors in 2000 Policy Plan and Metropolitan Planning Organization (MPO) long-range goals, then LRT and TODs place Memphis on par not just with exemplary airport cities, but also regional cities, comparable to Portland, San Jose, Salt Lake, and Charlotte with LRT and TODs (as cited in Memphis Area Transit Authority's (MATA) Regional Rail Program Report).The Memphis aerotropolis boundary is appropriately metropolitan region-wide, encompassing suburban municipalities in the tri-state region of Tennessee, Arkansas, and Mississippi (www.memphischamber.com). Whether Memphis's proposed boundary suggests an aerotropolis with a space-economy comparable to an exemplary European and Asian aerotropolis or a marketing desideratum remains to be determined. Hence, the challenges of the region-wide land use and transportation coordination that places the Memphis Aerotropolis on a path toward urban sustainability akin to a regional city-with multi-modal mobility options, connected corridors, and mixed-use centers-are also suggested.

\section{Discussion: From airport city and aerotropolis to regional city}

We sum up with the following observations toward addressing the question of sustainable urban form of the future. The aerotropolis has building blocks in common with the regional city. The metropolitan region is a common denominator, and thereby posing the urban sustainability challenge of a whole region 
that is more than the sum of the parts (building blocks): centers, districts, preserves, and corridors. The regional city's special purpose district accommodates the expansion of the city airport to an airport city. However, the airport city meets the regional city's density with mixed-use structures that support transit but encounter the challenges of a regional city's compact urban form of center with mixed land-use that supports transit-oriented developments. The industrial, commercial, business, office spaces, and hotels provide agglomerative economies for efficient business transactions, including personal communications that require physical presence in a regional milieu — an irony in our era of featureless cyberspace (see also Lynch 1984). There is much to commend about master-planned airport-oriented towns with pedestrian-friendly central business districts, mixed-use centers, and mixed land-use that are hallmarks of the regional city. However, city airports redeveloping as airport cities are parts (districts) of the larger metropolitan area. In the parlance of the regional city, urban sustainability is not determined by district alone. Corridors, centers, and preserves are the connecting building blocks of the sustainable regional city. Their relationship ensures that the aerotropolis is a sustainable metropolitan region. For example, Beijing International Airport City is part of a polluted, congested, and unsustainable Beijing metropoli$\tan$ region, albeit one in which neither air nor vehicular transportation are the major source of the GHG emissions.

The master-planned cities, with multi-modal links to the airport and central cities, as in Songdo with its connection to Incheon and Seoul, or with infill, redevelopment sites, as in Stapleton, Denver have the advantage of the compact urban form and mixed-use centers within a walking distance of homes. Zuidas similarly inherits Amsterdam's green urbanism including a compact urban form. Their residential population benefits from some separation (from the airport's negative externalities) but also the proximity to the airport that is regarded as a major employment node equal to or exceeding the CBD of the metropolitan region. As jobs balance with housing and services toward self-containment, and multimodal corridors ensure mobility and access to the metropolitan region's resources, then the aerotropolis - akin to regional city - is a sustainable urban form, whether evolved historically, or planned comprehensively, or redeveloped incrementally, as noted in the three examples in the paper. What of the Aerotropolis as a model for urban redevelopment in Memphis?

The airport-city area proper is a sub-area (fifty square mile) or district of the Memphis metropolitan region - now called an aerotropolis - that includes suburban municipalities. Therefore, sustainability/ livability aims that are called for in the comprehensive master plan of the airport city are critical to the redevelopment of the greater Memphis Aerotropolis — with transformation from city airport to airport city to regional city - until such time that corridors provide multi-modal regional mobility and accessibility to mixed-use job centers that are connected with public transit-ways, bikeways, and roads. Vacant and underutilized land provides infill options for the creation of pedestrian-friendly, mixed-income areas and mixed-use activity centers (see 2000 Policy Plan). Activity centers provide jobs-housing balance along the multi-modal transportation corridors throughout the metropolitan region; TOD corridors fill the sustainability gap with land use/transportation connection in otherwise-congested highway and arterial roads (see Banai 2006). The Memphis Aerotropolis, then, is also a regional city.

\section{Toward a sustainable urban form of the future}

The word "sustainable" is invoked in discussions of the regional city and the aerotropolis (e.g., Calthorpe and Fulton 2001; Wheeler 2009, 2000, 2002; Kasarda 2011, Banai 2013). We applied the regional-city building blocks toward an assessment of sustainable urban and regional form of the future. However, the regional city is the revival of the regionalism of the previous century, as noted at the outset. Does regionalism itself provide any clues on sustainability?

In the early decades of the twentieth century, a group of experts with diverse backgrounds that 
included journalism, socio-cultural criticism, social reform, economics, biology, sociology, forestry-naturalism, real estate development, and architecture formed the Regional Planning Association of America (RPAA). [For in-depth accounts of the philosophical underpinnings of the RPAA, see Friedmann and Weaver (1979), and Hall (1998, chapter 5).] It turns out that the RPAA's holistic perspective of the metropolitan region's building blocks is durable and relevant to the discourses of sustainable urbanism in the twenty-first century (see also Banai 2013). Hall (199 6, p. 151) paraphrased the RPAA economist Stuart Chase with the following observation:

"Much of the American economy [around the turn of the century] consisted in carrying 'coals to Newcastle,' moving goods across the continent that had no need to be moved at all." The solution, according to Chase, is regional planning (quoted in Hall 1996):

"The regional planning of communities would wipe out uneconomical national marketing, wipe out city congestion and terminal wastes, balance the power load, take the bulk of coal off the railroads, eliminate the duplication of milk and other deliveries, short circuit such uneconomic practices as hauling Pacific apples to New York customers by encouraging local orchards, develop local forest areas and check the haulage of western timber to eastern mills, locate mills near cotton fields, shoe factories near hide producing areas, steel mills within striking distance of ore beds, food manufacturing plants in small giant power units, near farming belts." (pp. 151-152)

Chase would likely regard Columbian or Aalsmeer's flowers, New Zealand apples, or South American or European meat flown to North American supermarkets as unsustainable in the twenty-first century, even if facilitated by an airport-city infrastructure that accelerates efficient and speedy flows of goods and services from all over the world. He would likely consider the urban hinterland's productive agricultural belt as the place that sustainably caters to the demand of the urbanites. A century later Kasarda and Lindsay $(2011,212)$ remark, "It's been left to us, however, whether roses grown in Kenya are too far a flight away in the face of climate change, a debate than encompasses more than just mileage."

Wackernagel and Rees (1996) use a definition of "ecological footprint" that determines the amount of land used for consumption and waste in cities. With an ecological footprint calculation example for the Netherlands, it is concluded that the Dutch territory's land area would need to be nearly fifteen times its current size to sustain the 1991 population with an ecological footprint of 3.32 hectares per capita (p 296). In 2012, the Netherlands' ecological footprint increased to 6.34 global acres per capita (GFN 2012; see also Pierce 2007). Wackernagel and Rees $(1996,295)$ further remark that "if everyone on Earth lived like the average Canadian or American, we would need at least three such planets to live sustainably." The regional-city building blocks represent a framework toward assessing sustainable urban form. The ecological footprint provides yet another indicator of environmental sustainability laden with physical manifestation and relevant to the question of the sustainable urban form of the future, be it in the form of the regional city or the aerotropolis. A country-specific calibration should determine whether the airport city's building blocks are footprints that reflect not only the place- and time-tested durable regional city but also the eco-centric principles of environmental sustainability.

Furthermore, the regional city's building blocks defined by Calthorpe and Fulton (2001)--centers, districts, preserves, corridors - exhibit some affinity with elements that Lynch (1960) defined the quality and legibility of the city form: paths, edges, nodes, districts, and landmarks. The assessment of the aerotropolis's physical formal quality plausibly extends the functional (logistical), spatial (land use) and economic (sector) analysis commonly recorded in the literature. That assessment should reveal whether 
the aerotropolis is an urban from of the future distinguished by legibility of its formal quality or the chaotic, sprawling city of the past (see also Appleyard, Lynch, and Meyer 1965; Lynch 1976).

\section{Conclusion}

The city airport's transformation to airport city has received attention mainly limited to the space-economic, logistics, and transportation infrastructure at a subregional node of a polycentric metropolitan region with a cluster of aviation-related industry, business, and commerce. The airport city that is an aerotropolis, however, must be regarded as part of the larger metropolitan region. The architecture of that larger metropolitan region is not adequately addressed in the aerotropolis literature. We have argued the relevance of the metropolitan-wide, regional-city building blocks - centers, districts, preserves, corridors - toward an assessment of the airport city's urban form. Discussions of urban sustainability commonly invoke the regional-city building blocks and cite as evidence exemplary American, European, and Asian regional cities, such as Portland, Salt Lake, Seattle, Vancouver, Stockholm, and Singapore. Concomitantly, the strengths and vulnerabilities of the aerotropolis as a sustainable urban form of the future are suggested with regional-city building blocks.

The compact urban form — with mixed land-use, housing, jobs, and services in proximity—promotes walkability and transit use, improves air quality due to reduced tail-pipe pollution, and lessens reliance on non-renewable energy sources. The challenge is to incorporate features of a sustainable urban form into the airport city district, which consists of structures with large footprints, such as industrial, manufacturing, warehousing, particularly in existing land area surrounding airport terminal buildings. Recall that airports and their ancillary facilities are allocated to the regional city's district in order to sustain the pedestrian-friendly regional-city center at any scale-from village to town to region.

The mixed land-use in the central business district like its historic Main-Street counterpart contributes to the city's viability. The challenge is to sustain the viability of the airport city's mixed-use districts in a polycentric metropolitan region of the future, ensuring that the airport city's district is in a sustainable metropolitan region.

A distinguishing feature of the sustainable city of the future is the quality of its physical form. The challenge is to enhance the legibility of the district's formal quality, particularly with redevelopment of the city airport's chaotic, sprawling, auto-centric urban form. The legible city is symbolically determined by the strength of the relationships among the elements: paths, edges, nodes, districts, and landmarks. Recall that the Lynch-type elements that define the legibility or image of the city form operate at any scale - from building to district to region. The elements' relevance and the structure of their connections that determine the image of the city is suggested in the discussion of place-making with node vs. place distinction in the airport city literature. Following Lynch, the aviation-centric CBD is symbolically determined not by node alone (i.e. main terminal facility, however prominent), but by the strength of the nodal connections with paths, edges, and the district as a whole. The recent tree-lining of major roads that terminate at the Memphis airport is one example of strengthening the legibility/image of pathnode connection (e.g., see LRK 2013). However, the view from the road in surrounding land-use with dilapidated structures signifies the challenges of inequality and poverty in the sprawling city. Add the "twin problems of sprawl and inequity" (Calthorpe and Fulton 2001, 11) to the "twin calamities of peak oil and climate change" (Kasarda and Lindsay 2011, 21).The United Nations commission reports and millennium declarations on environment and development remind us that environmental sustainability is not attained without eradicating poverty (UN 1987, 2003, 2005, 2009; see also Worldwatch Reports, worldwatch.org; and Brown 2011). The twenty-first century city is challenged by enduring poverty, and not even in the regional city poverty is entirely eliminated. 
The urban form of the future is a polycentric region with mixed-use centers containing multimodal corridor connections. The challenge is to insure that the sprawling, car-dependent metropolis is reconfigured in an aerotropolis that resembles the pedestrian-friendly regional city that balances jobs with housing and services and thereby provides both mobility and access throughout the metropolitan area. Furthermore, the region city's hinterland — the agricultural, horticultural, floricultural belt — caters to the local urban population. Businesses and industries take advantage of the economies of location with the region's prime productive land, labor pool, and proximity to market. The regional city's solution to climate change lies in its own urban hinterland, rather than the aerotropolis's a "continent away" (Kasarda and Lindsay 2011, 21).

Arguably, the redevelopment of airport-area properties encounters the challenges of the regional city principles of compactness, walkability, centers with mixed land-use and multimodal corridor connection differently than an airport city that is master planned "all of a piece." Note that the regional city itself "externalizes" an urban form (large building footprints, long blocks) that is not compatible with the pedestrian-friendly scale of centers to districts.

The transformation of the airport city to the regional city provides a pathway toward a sustainable aerotropolis in the twenty-first century. However, the transformation heeds the notion of the twentyfirst century not only as an urban century and an aviation era, as Kasarda and Lindsay (2011) characterized, but also as an ecological era. The ecological era poses anew the regional-city principles of urban sustainability while reminding that global urbanization of population with an increasing ecological footprint endangers not just the planet Earth but "civilization itself" (see Brown's 2011 Journey to Planet Earth). The physical form of cities and their regions - which induces vehicular travel—is linked to greenhouse gases with consequences for climate change. The aerotropolis's urban form and function is similarly linked to environmental consequences, due to air transportation. The regional city anchors discussions of environmental sustainability — economic (efficiency), ecological (viability), and social (equity) - firmly in place and space with an emphasis on physical form and function.

Proponents of a transit-oriented development argue that mixed housing types that cater to a diverse population, mixed-use center that contains retail, office, and commercial spaces within a walking distance of housing are features of a sustainable urbanism whether or not the center is also a rail-transit or bus rapid-transit stop. Arguably, the regional-city building blocks similarly render a sustainable urban form whether or not air transportation is the dominant mode of a multi-modal aerotropolis of the future.

Further research plausibly extends the assessment of the aerotropolis beyond the building blocks of the physical form. Indicators, like an ecological footprint, aid in an expansive assessment of environmental sustainability, revealing the durability of the aerotropolis as the city of the future as well as its Achilles' heel.

\section{$7 \quad$ Acknowledgements}

Comments of the editors and reviewers of the Journal of Transport and Land Use on an earlier version of this paper are gratefully acknowledged.

Daniel Guerra-Monje, Department of Earth Sciences and Parsa Pezeshk, Department of Civil Engineering at the University of Memphis contributed to research and discussion of the spatial structure of American, European, and Asian aerotropolis with regional city building blocks. 


\section{References}

Alexander, C. 1965. The city is not a tree. Architectural Forum 122: 1, 2.

Appleyard, D., K. Lynch, and J. R. Myer. 1965. The View from the Road. Cambridge, MA: MIT Press.

Appold S. J., and J. D. Kasarda. 2013. The airport city phenomenon: Evidence from large US airports. Urban Studies 50(6): 1239-1259.

Atzema O. 1999. Economic dynamics in the Randstad Holland: Do agglomeration economies still exist? In Regional Development in an Age of Structural Economic Change, edited by P. Rietveld and D. Shefer. Aldershot, UK: Ashgate.

Banai, R. 2013. The metropolitan region: From concepts to indicators of urban sustainability. Journal of Urbanism: International Research on Placemaking and Urban Sustainability 6(1): 1-23.

Banai, R. 2006. Public transportation decision-making: A case analysis of the Memphis light rail corridor and route selection with the analytic hierarchy process. Journal of Public Transportation 9(2): $1-24$.

Banai, R. 1998. The new urbanism: An assessment of the core commercial areas, with perspectives from (retail) location and land-use theories, and the conventional wisdom. Environment and Planning B: Planning and Design 25: 169-185.

Banister, D., ed. 1995. Transport and Urban Development. London: E. \& F. N. Spon.

Barnett, J. 2011. City Design: Modernist, Traditional, Green and Systems Perspectives. New York: Routledge.

Beatley, T. 2009. Planning for sustainability in European cities: A review of practices in leading cities. In The Sustainable Development Reader, edited by S. M. Wheeler and T. Beatley, 330-339. London: Routledge.

Bernick, M., and R. Cervero. 1997. Transit Villages in the 21st Century. New York: McGraw-Hill.

Birch, E. L., and S. M. Wachter, eds. 2008. Growing Greener Cities: Urban Sustainability in the TwentyFirst Century. Philadelphia: University of Pennsylvania Press.

Blanton, W. 2004. On the airfront. Planning 70(5): 34-35.

Breheny, M., ed. 1992. Sustainable Development and Urban Form. London: Pion.

Breheny, M. 1996. Centrists, decentrists, and compromisers: Views on the future of urban form. In The Compact City: A Sustainable Urban Form? edited by M. Jenks, E. Burton, and K. Williams, 13-45. London: E. \& F. N. Spon.

Brown, L. 2011. Plan B: Mobilizing to save civilization. Journey to Planet Earth. https://www.youtube. com/watch?v=PEzmcgqmNj0.

Brown, S. 1990. Retail location: The post hierarchical challenge. The International Review of Retail Distribution and Consumer Research 1: 367-381.

Brown, S. 1992. Retail Location: A Micro-Scale Perspective. Aldershot, UK: Avebury.

Burgess, E. W. 1923. The growth of the city. Proceedings of the American Sociological Society 18: 85-89.

Calthorpe, P. 2011. Urbanism in the Age of Climate Change. Washington, DC: Island Press.

Calthorpe, P. and W. Fulton. 2001. The Regional City: Planning for the End of Sprawl. Washington, DC: Island Press.

Calthorpe, P. 1993. The Next American Metropolis-Ecology, Community, and the American Dream. New York: Princeton Architectural Press.

Duany A., and E. Talen, eds. 2013. Landscape Urbanism and its Discontents: Dissimulating the Sustainable City. Gabriola Island, BC, Canada: New Society Publishers.

Ewing, R., K. Bartholomew, S. Winkelman, J. Walters, and G. Anderson. 2008. Urban development and climate change. Journal of Urbanism: International Research on Placemaking and Urban Sustain- 
ability 1(3): 201-216.

Farr, D. 2008. Sustainable Urbanism: Urban Design with Nature. Hoboken, NJ: John Wiley \& Sons, Inc.

Fishman, R. 2000. The death and life of American regional planning. In Reflections on Regionalism, edited by B. Katz, 107-121. Washington, DC: The Brookings Institution.

Flint, A. 2006. The Battle Over Sprawl and the Future of America. Baltimore, MD: Johns Hopkins University Press.

Freestone, R., and D. Baker. 2011. Spatial planning models of airport-driven urban development. Journal of Planning Literature 26: 263.

Freestone, R. 2009. Planning, sustainability and airport-led urban development. International Planning Studies 14(2): 161-176.

Friedmann, J., and C. Weaver. 1979. Territory and Function: The Evolution of Regional Planning. Los Angeles, CA: UCLA Press.

Garreau, J. 1991. Edge City: Life on the New Frontier. New York: Double Day.

Global Footprint Network (GFN). 2012. The Netherlands. http://www.footprintnetwork.org/images/ trends/2012/pdf/2012_netherlands.pdf.

Greater Memphis Chamber. 2013. Memphis: America's Aerotropolis. Accessed 8/21/2014. http://www. memphischamber.com/The-Chamber/Councils/Aerotropolis.aspx.

Hall, P., and C. Pain. 2006. The Polycentric Metropolis: Learning from the Mega-City Regions in Europe. London: Earthscan Publications.

Hall, P. 2001. Global city-regions in the twenty first century. In Global City Regions: Trends, Theory, Policy, edited by A. J. Scott, 59-77. Oxford: Oxford University Press.

Hall, P. 1996. Cities of Tomorrow. Oxford: Blackwell.

Hakfoort J., T. Poot, and P. Rietveld. 2001. The regional economic impact of an airport: The case of Amsterdam Schiphol Airport. Regional Studies 35(7): 595-604.

Harris, C. D., and E. L. Ullman. 1945. The nature of cities. Annals of the Academy of Political and Social Science 242: 7-17.

Hotelling, H. 1929. Stability in Competition. Economic Journal 39(153): 41-57.

Howard, E. 1902. Garden Cities of To-morrow (formerly To-morrow: A Peaceful Path to Real Reform, published in 1898). London: Swan Sonnenschein.

Hoyt, H. 1939. The Structure and Growth of Residential Neighborhoods in American Cities. Washington DC: Government Printing Office.

Jenks, M., E. Burton, and K. Williams, eds. 1996. The Compact City: A Sustainable Urban Form? London: E. \& F. N. Spon.

Kasarda, J. D. 2011. Aerotropolis: The way we'll live next? Atlantis 22(3): 12-14.

Kasarda, J. D. 2006. Asia’s emerging airport cities. International Airport Review 10(2): 63-66.

Kasarda, J. D. Aerotropolis. http://aerotropolis.com

Kasarda J. D., and G. Lindsay. 2011. Aerotropolis: The Way We'll Live Next. New York: Farrar, Straus and Giroux.

Katz, B., ed. 2000. Reflections on Regionalism. Washington, DC: Brookings Institution.

Kotkin, J. 2007. The City: A Global History. New York: Random House.

Lang, J. 1984. Urban Design: The American Experience. New York: Van Nostrand Reinhold.

Lang, R. 2003. Edgeless Cities: Exploring the Elusive Metropolis. Washington, DC: Brookings Institution Press.

Lee, R. W., G. D. Gosling, and K. Irvin. 2008. Applying Smart Growth Principles and Strategies to Resolving Land Use Conflicts Around Airports. San Jose, CA: Mineta Transportation Institute. 
Lindsay, G. 2006. Rise of the aerotropolis. Fast Company, July/August. http://www.fastcompany. com/57081/rise-aerotropolis.

Lindsay, G., and J. D. Kasarda. 2013. Aerotropolis: The way we'll live next. New York: Farrar, Straus and Giroux.

LRK. 2013. Memphis Aerotropolis Urban Design Guide. City of Memphis, Tennessee. LRK Inc., September 11, 2013.

Lynch K. 1976. Managing the Sense of a Region. Cambridge: The MIT Press.

Lynch, K. 1960. The Image of the City. Cambridge: The MIT Press.

Lynch, K. 1984. Good City Form. Cambridge: The MIT Press.

Markusen, A., and P. Saxenian. 1986. High-Tech America: The What, How, Where, and Why of the Sunrise Industries. London: Allen and Unwin.

McHarg I., Steiner F. 2006. The Essential Ian McHarg_Writings on Design and Nature. New York: Island Press.

McHarg I. L. 1969/1995. Design with Nature. New York: John Wiley \& Sons.

Memphis Area Transit Authority. 2007. Regional Rail Program Report, Downtown Airport Corridor. www.matatransit.com.

Memphis and Shelby County Office of Planning and Development. 1981. Memphis 2000 Policy Plan. http://www.shelbycountytn.gov/DocumentCenter/Home/View/3350.

Moore, S. A. 2007. Alternative Routes to the Sustainable City: Austin, Curitiba, and Frankfurt. Lanham, MD: Lexington Books.

Pastor Jr., M., P. Dreier, J. E. Grigsby, and M. Lopez-Garza. 2000. Regions That Work. Minneapolis, MN: University of Minnesota Press.

Pierce, J. 2007. 2003. World consumption cartogram. http://pthbb.org/natural/footprint/; http://www. footprintnetwork.org/en/index.php/GFN/page/trends/netherlands/.

Rabinovitch, J., and J. Leitman. 1996. Urban planning in Curitiba. Scientific American, March 1: 46-53

Rietveld P. and F. Bruinsma. 1998. Is transport infrastructure effective? Springer-Verlag Berlin Heidelberg. Ross, C. L., ed. 2009. MegaRegions: Planning for Global Competitiveness. Washington, DC: Island Press. Schaafsma, M., J. Amkreutz, and M. Gukker. 2008. Airport and City: Drivers of Economic Development. Amsterdam: Schiphol Real Estate.

Songdo Master Plan. 2014. Gale International, LLC. http://www.songdo.com/songdo-internationalbusiness-district/the-city/master-plan.aspx.

Thorpe, J. 2013. Songdo IBD: A City Built from Scratch. http://www.globalairportcities.com/.

Twomey, J, and J. Tomlins. 1995. Development effects at airports: A case study of Manchester airport. In Transport and Urban Development, edited by D. Banister. London: E. \& F. N. Spon.

UN Habitat. 2009. Planning Sustainable Cities: Global Report on Human Settlements. London: EarthScan, United Nations Human Settlements Program.

UN Millennium Project. 2005. Investing in Development: A Practical Plan to Achieve Millennium Development Goals. Washington, DC: Communications Development.

UN Human Settlements Program. 2003. The Challenge of Slums: Global Report on Human Settlements. London: EarthScan.

UN. 1987. Report of the World Commission on Environment and Development: Our Common Future. New York: The World Commission on Environment and Development, United Nations.

Van Wijk, M., K. Brattinga, and M.A. Bontje. 2011. Exploit or protect airport regions from urbanization? Assessment of land-use restrictions in Amsterdam-Schiphol. European Planning Studies 19: 261-277.

Vision Zuidas. 2009. http://www.amsterdam.nl/zuidas/documenten-basis/algemene-documenten/ 
visie-zuidas-2009/.

Wackernagel, M., and W. Rees. 2009. What is an ecological footprint? In The Sustainable Urban Development Reader, edited by S. M. Wheeler and T. Beatley, 289-297. New York: Routledge.

Wheeler, S. M. 2000. Planning for metropolitan sustainability. Journal of Planning Education and Research. 20(2): 133-145.

Wheeler, S. M. 2002. The new regionalism: Key characteristics of an emerging movement. Journal of the American Planning Association 68(3): 267-278.

Wheeler, S. 2009. Regions, megaregions, and sustainability. Regional Studies 43(6): 863-876.

Williamson, L. 2013. Tomorrow's cities: Just how smart is Songdo? BBC News-Technology (September 1, 2013) London: British Broadcasting Corp.

Worldwatch Institute. 2016. Can a City be Sustainable? State of the World (2016). Washington, D.C.: Island Press. www.worldwatch.org.

Yaro, R. D., and D. M. Kooris. 2008. Growing greener regions. In Growing Greener Cities: Urban Sustainability in the Twenty-First Century, edited by L. Birch and S. M. Wachter, 28-45. Philadelphia: University of Pennsylvania Press.

Yu, R. 2011. Cities build airport cities aerotropolises for growth. USA Today (April 20). McLean, VA: USA Today. 